\title{
Correction to: The role of work-based \\ learning for student engagement in vocational \\ education and training: an application \\ of the self-system model of motivational development
}

\author{
Ward Nouwen $^{1} \cdot$ Noel $^{\text {Clycq }^{2}}$ (D) $\cdot$ Annemie Struyf $^{1} \cdot$ Vincent Donche $^{2}$ \\ Published online: 2 February 2022 \\ (C) Instituto Universitário de Ciências Psicológicas, Sociais e da Vida 2022
}

\section{Correction to: European Journal of Psychology of Education \\ https://link.springer.com/article/10.1007/s10212-021-00561-1}

The version of the article that is published online unfortunately is the anonymized version of the paper. Throughout the paper and in the bibliography, the references to the authors' publications are referred to as (author, YEAR). Below we provide the correct references.

Authors. (2017).

- Should be changed in the reference list to:

Van Praag, L., Van Caudenberg, R., Nouwen, W., Clycq,. N \& C. Timmerman (2017) How to support and engage students in alternative forms of education and training? A qualitative study of school staff members in Flanders. Journal of Education and Work, 30(6), 599-611.

- Should be changed in the text into: (Van Praag et al., 2017)

The online version of the original article can be found at https://oi.org/10.1007/s10212-021-00561-1

Noel Clycq

noel.clycq@uantwerpen.be

Ward Nouwen

ward.nouwen@uantwerpen.be

Annemie Struyf

annemie.struyf@uantwerpen.be

Vincent Donche

vincent.donche@uantwerpen.be

1 Centre for Migration and Intercultural Studies, Faculty of Social Sciences, University of Antwerp, Antwerp, Belgium

2 Department of Training and Education Sciences, Faculty of Social Sciences, University of Antwerp, Antwerp, Belgium 
Authors. (2018).

This reference can be omitted from the reference list and in the text it can be changed into (Nouwen et al. 2019b)

Authors. (2019a).

- Should be changed in the reference list to:

De Loof, H., Struyf, A., Boeve-de Pauw, J., \& Van Petegem, P. (2019). Teachers' motivating style and students' motivation and engagement in STEM: The relationship between three key educational concepts. Research in Science Education, 1-19.

- Should be changed in the text into: (De Loof et al., 2019)

Authors. (2019b).

- Should be changed in the reference list to:

Nouwen, W., \& Clycq, N. (2019). The role of social support in fostering school engagement in urban schools characterized by high risk of early leaving from education and training. Social Psychology of Education, 22(5), 1215-1238.

- Should be changed in the text into: (Nouwen \& Clycq, 2019b)

Authors. (2020).

- Should be changed in the reference list to:

Van Caudenberg, R., Nouwen, W., Struyf, A. \& Clycq, N. (2020). Duaal leren: kansen en uitdagingen voor kwetsbare jongeren in grootsteden. In J. Coene, Hubeau B., Remmen R., Vandenhole W., Van Haarlem A., Marchal S. \& T. Ghys (Eds.), Armoede en sociale uitsluiting: jaarboek 2020 (pp. 153-171). Leuven: ACCO.

- Should be changed in the text into: (Van Caudenberg et al., 2020)

The original article has been corrected.

Publisher's note Springer Nature remains neutral with regard to jurisdictional claims in published maps and institutional affiliations. 